\title{
Sea cucumber as bioindicator of trace metal pollution in coastal sediments
}

\author{
José Marrugo-Negrete ${ }_{1,{ }^{*},}$ José Pinedo-Hernández1, Siday Marrugo-Madrid1,3, \\ Enrique Navarro-Frómeta2, Sergi Díez3,*
}

1University of Córdoba, Carrera 6 No. 76-103, Montería, Córdoba, Colombia

2Food and Environmental Technology Department, Technological University of Izucar de Matamoros, Izucar de Matamoros, Mexico

${ }_{3}$ Environmental Chemistry Department, Institute of Environmental Assessment and Water Research, ID/EA-CSIC, E-08034 Barcelona, Spain

* Corresponding authors:

E-mail: jmarrugo@correo.unicordoba.edu.co (J.Marrugo-Negrete), sergi.diez@idaea.csic.es (S.Díez) 


\section{Abstract}

Sea cucumbers are fished worldwide for export to Asia, but few studies have evaluated metal pollution and risk assessment. This study assessed concentration of trace metals and the potential ecological risk in sea cucumber (Holothuria floridana) and sediments at the Cispatá Bay, in the Caribbean coast of Colombia. The trace metal concentrations in biota and sediments showed a similar decreasing trend as follows: $\mathrm{Cu}>\mathrm{Zn}>\mathrm{Hg}>\mathrm{Pb}>$ $\mathrm{Cd}$. The highest bioconcentration factor was found for $\mathrm{Hg}$, and according sediment quality guidelines, $\mathrm{Cu}$ levels indicate adverse biological effects in the ecosystem. In this regard, $\mathrm{Cu}$ levels were higher than effects range low and the threshold effect levels (TEL) and lowest effect level in all the stations, whereas $\mathrm{Hg}$ levels were higher than TEL in most of them. Results for health risk assessment based on the maximum allowable daily consumption rate $\left(\mathrm{CR}_{\text {lim }}\right)$ suggest that there is no risk to adults, however children should limit or avoid its consumption. Results from multivariate statistical analysis suggest that agricultural activities (i.e. application of fertilizers and agrochemicals) were identified as the main anthropogenic sources of metal pollution. This research suggest that sea cucumber could be used as a bioindicator species in studies of monitoring metal contamination, with special attention to the highly significant correlation between $\mathrm{Zn}$ in tissue and sediments. This study also reveals that anthropic activities may have negative effects in the quality of the sediments of the bay and contributing to the knowledge of metal accumulation in sea cucumber.

Keywords: Holothuria floridana; metals, sea cucumber; sediments; Cispatá Bay; Colombia. 


\section{Introduction}

Different anthropogenic stressors, such as climate change, marine transportation and land based sources of pollution, have the potential to adversely impact marine ecosystems, so environmental assessment of pollutants is a critical issue for ecosystems management [1] Globally, pollution by metals is one of the most critical problems for marine aquatic ecosystems because some toxic elements tend to bioaccumulate in organisms (echinoderms, bivalves, crustaceans, etc.) and sediments, exerting harmful effects on organisms and human health by biomagnification in the food chain $[2,3]$. In aquatic ecosystems, sediments are the main sink and source of metals, serving as the largest pool for the storage of toxic metals [4]. Due to the variabilities of metals in the water column, the sediments usually provide more information to understand different dynamics of metals in the aquatic environment.

Sea cucumbers (Holothuroidea) are invertebrates that move slowly and live in contact or buried in the sediment; they have an essential role in the marine ecosystem by recycling nutrients, and therefore they can directly accumulate metals from the sediment because it is their food source $[5,6]$. Consequently, a scientific interest focused on the use and conservation of sea cucumber has increased in recent years [7-9]. These organisms have been considered appropriate to be used as biomonitors because they have certain characteristics such as type of feeding, easy identification, low mobility, and small size, although with enough tissue to perform analysis of contaminants [10, 11].

On the other hand, sea cucumbers are highly prized in Asia and sold as trepang or bêchede-mer, a dried product that is exported worldwide to Asian seafood markets [12], where is eaten for its health and medicinal benefits [13, 14]. Given the high demand for this resource, mainly by Asian countries such as China, Korea or Japan, overexploitation of sea cucumber fishing has led to the closure of some fisheries in the Pacific Island countries, and has expanded in the catch in other coasts of the world, including Latin 
American: Peru, Ecuador, Chile, Cuba, Costa Rica and Colombia [6, 7, 15]. Thus, in these countries sea cucumber is not consumed locally but has awakened export interests due to the high prices in the international market. One of the sea cucumber species, Holothuria floridana is found in the Gulf of Mexico, Cuba, Florida, Bahamas, Puerto Rico, Aruba, Jamaica, The Lesser Antilles, Honduras, Venezuela, Panamá, and Colombia. In the last two decades, fisheries have begun in Latin America and the Caribbean, which, according to reports and studies, are mostly unsustainable [7].

The Cispatá bay is a protected mangrove swamp and a highly productive ecosystem located in the Caribbean Sea of Colombia. It is delimited on the west by the Sinú River, on the south by the Sicará channel and the Soledad swamp, and on the north by the Caribbean Sea [16, 17]. Currently, the bay is surrounded by areas with intensive agriculture, livestock and a great variety of commercial fisheries (including shrimp and tilapia), and also with touristic activities that have experienced a fast growth. This area has been reported to be impacted by indiscriminate discharges of untreated sewage, industrial and domestic solid wastes and wastewaters from agricultural activities and livestock [18]. Recent studies indicated that sediments, fish and seabirds were polluted by indiscriminate discharges of untreated wastewater, industrial and domestic solid waste, wastewater from agricultural and livestock activities, and spills of harmful substances such as hydrocarbons [19-21]. Additionally, high concentrations of metals have been reported in the middle and lower basin of the Sinú River, which flows into the study area [21-23]. These evidences place in the foreground the problem of metal pollution in the Cispatá bay, where $H$. floridana could be found. Despite the ecological and economic importance of sea cucumbers, there is scarce information on metals levels in sea cucumbers worldwide, and no information in the Caribbean Coast. 
The main aims of this study were (i) to determine the concentrations of metals in sea cucumber and sediments, (ii), to calculate the ecological risk of metals on sea cucumber by means of pollution indices, and (iii) to evaluate if sea cucumbers are good bioindicators.

\section{Materials and Methods}

\subsection{Study area}

The Cispatá Bay is a protected mangrove swamp of 11000 ha, located in the Colombian Caribbean Coast (Department of Cordoba), between $09^{\circ} 25^{\prime} 12^{\prime \prime}-09^{\circ} 20^{\prime} 8 " \mathrm{~N}$ and $75^{\circ} 47^{\prime} 37^{\prime \prime}-$ $75^{\circ} 55^{\prime} 30^{\prime \prime} \mathrm{W}$ (Figure 1). In addition, the study site area might be impacted by the offshore oil terminal activity situated in Coveñas.

\subsection{Collection and analysis of samples}

The locations of the selected sampling stations are shown in Figure 1. Sampling of the Florida sea cucumber $(H$. floridana) was carried out by diving and manual collection, considering similar sizes [24]. From each station, eight specimens of $H$. floridana were taken (mean (SD) length: $16.5(2.9) \mathrm{cm}$; weight: $115.4(28.9) \mathrm{g})$. At the same sampling site, one composite sediment sample was collected from at least 4 subsamples using a Van Veen grab sampler. Sediments and organisms were placed in plastic bags, labeled, packed in ice and transported to the laboratory. Once in the lab, the sediments were dried

in an oven at $40{ }^{\circ} \mathrm{C}$ for $48 \mathrm{~h}$, and the organisms were dissected using stainless steel scissors and a lancet after filtering. The samples tissues were kept in sterile polythene bags in a freezer at $-20^{\circ} \mathrm{C}$ until analysis. The analytical method used to determine $\mathrm{Hg}$ concentration in the sediments and tissue samples (30 mg, dry weight, $\mathrm{dw}$ ) was based on thermal decomposition with detection by atomic absorption spectrometry using a milestone DMA-80 (Direct Mercury Analyzer) [25]. For $\mathrm{Cu}, \mathrm{Zn}, \mathrm{Cd}$ and $\mathrm{Pb}$ analysis, sediments and tissues were digested with $\mathrm{HNO}_{3} / \mathrm{HCl}(1: 3 \mathrm{v} / \mathrm{v})$ using Method $3051 \mathrm{~A}$ [26], and according to 
the procedure described by Karadede and Ünlü (2007) [27], respectively. Analyses were performed using a Thermo Elemental Solaar S4 coupled flame spectrometer for $\mathrm{Cu}$ and $\mathrm{Zn}$ and graphite furnace for $\mathrm{Cd}$ and $\mathrm{Pb}$. The method was validated with IAEA-405 and DORM-2, and the recovery average percentages $(n=3)$ for metals were $94.6 \%$ (sediment) and $96.2 \%$ (tissue).

\subsection{Bioconcentration factor}

The bioconcentration factor (BCF) biota-sediment, expressed as the ratio of the metal concentration in the tissue to the metal concentration in the sediment [28], was estimated using the obtained concentrations of metals. The BCF of metals by organism occurs when BCF $>1[29]$.

\subsection{Pollution and ecological risk assessment}

The contamination degree was calculated in function of the pollution load index (PLI), the potential ecological risk assessment (RI), the sediment quality guidelines (SQG), and the mean ERM Quotient (M-ERM-Q) (Table 1) as previously described elsewhere [30]. Background levels for metals in sediment were obtained by taking a core depth of $45 \mathrm{~cm}$ collected at station 5 , subdivided into $1 \mathrm{~cm}$ layers and subsequent analysis of metals were performed for each fraction. The baseline or background values were: $\mathrm{Hg} 0.042 \mu \mathrm{g} / \mathrm{g}, \mathrm{Cu}$ $9.77 \mu \mathrm{g} / \mathrm{g}, \mathrm{Pb} 0.032 \mu \mathrm{g} / \mathrm{g}, \mathrm{Cd} 0.015 \mu \mathrm{g} / \mathrm{g}$ and $\mathrm{Zn} 21.14 \mu \mathrm{g} / \mathrm{g}$.

\subsection{Human health risk assessment}

Due to lack of available data on the estimated daily intake of sea cucumber from both exporting and importing countries, quantifying risks is more challenging. To this purpose, a good approach is possible by calculating the maximum allowable daily sea cucumber consumption rate $\left(\mathrm{CR}_{\text {lim }}\right)$, according to the USEPA [31] equation $\mathrm{CR}_{\text {lim }}=(\mathrm{RfD} \times \mathrm{BW}) \times \mathrm{C}_{-1}$; 
where reference dose $(\mathrm{RfD})$ is the daily oral exposure to the human population that is likely to be without an appreciable risk of deleterious noncancer effects during a lifetime, BW is consumer body weight, and $\mathrm{C}$ is the mean metal concentration of sea cucumber.

Values of CRlim for $H$. floridana based on a contaminant's noncarcinogenic health effects, was expressed in kilograms per day. RfDs values (Table 2) were taken from USEPA [32] and WHO [33], values for BW of $15 \mathrm{~kg}$ for children and $80 \mathrm{~kg}$ for adults, were assumed

according USEPA recommendation [34]. Because no oral RfDs value for $\mathrm{Pb}$ exists, a reference value for $\mathrm{Pb}$ (Table 2) was taken from the European Food Safety Authority [35].

\subsection{Statistical analysis}

The results for each sample were expressed as the mean \pm the standard deviation (SD) of three replicates. A Student's t-test was used to evaluate if there were significant differences between the average concentrations from different sampling stations. The criterion for significance was set at $p<0.05$. Principal component analysis (PCA) with Varimax rotation was employed with the aim of identifying associations and possible origin among metals. The results from the PCA were interpreted according to the hypothetical sources of trace metals. Statistical analysis was performed with SPSS v23.0.0.0.

\section{Results and discussion}

\subsection{Metal concentrations in tissue and sediment samples}

Concentrations of metals in tissue and sediment samples in each sampling site are shown in Figure 2. Concentrations of metals (in $\mu \mathrm{g} / \mathrm{g}$ ) in tissues ranged from 7.72-9.67 (Cu), 5.39$8.03(\mathrm{Zn}), 0.074-0.090(\mathrm{Hg}), 0.030-0.038(\mathrm{~Pb})$ and $0.016-0.026(\mathrm{Cd})$; while in sediments 53.85-62.87 (Cu), 46.53-58.21 (Zn), 0.102-0.148 (Hg), 0.088-0.122 (Pb) and 0.053-0.078 (Cd). The descending order as a function of the average concentrations of metals in tissue and sediments was $\mathrm{Cu}>\mathrm{Zn}>\mathrm{Hg}>\mathrm{Pb}>\mathrm{Cd}$. The concentrations of metals in tissue and 
sediments do not present statistically significant differences for the different sampling stations $(p>0.05)$. This indicates that, although organisms and sediments could have been exposed to different degrees of metal pollution levels, there are no spatial variations.

The concentrations of $\mathrm{Cu}$ and $\mathrm{Zn}$ were lower in tissues than in sediments, probably because they are essential elements of great importance in many functional roles and they are co-factor for numerous enzymes that were regulated by sea cucumber tissues $[29,36$, 37]; however, the accumulation of metals in organs depends on intrinsic and extrinsic factors to the organism $[38,39]$. The accumulation of metals in sediments is consequence of the geochemical processes that occur in situ and in flooded soils, the discharges of sewage from population centers and primary, agro-industrial, tourist and industrial activities that take place around the Cispatá bay [17, 18, 21]. Additionally, the influence of the Sinú River should be considered since high concentrations of metals have been reported in sediments and soils of its middle-low basin that can reach the study site by runoff, dragging and subsequent deposition [19, 20].

Despite $\mathrm{Hg}, \mathrm{Pb}$, and $\mathrm{Cd}$ were the least accumulated elements in the tissue, their relatively low concentrations in the tissue do not rule out their potential risk, because these metals are precursors of toxic effects of great impact over time. In addition, since sediments are the main sink of metals from the water column, and therefore the food source of metals for $H$. floridana, those can be assimilated and bioaccumulated in their tissues for further biomagnification in the food chain [36, 40,41]. Moreover, there are numerous factors that influence the accumulation of elements in living organisms: characteristics of the accumulated elements (essential or non-essential, solubility in water, form, etc.), concentration, exposure time, presence of other elements or compounds in the environment, physicochemical parameters of the environment, habitat, diet, sex, and metabolic rate of the organism in some cases [39, 42]. 
The efficiency of bioaccumulation of metals in $H$. floridana was evaluated by calculating BCF values. The bioaccumulation of metals by organism occurs if BCF $>1$ [29]. Results showed that $\mathrm{Hg}(0.612)$ has much higher average values of BCF compared to $\mathrm{Cu}(0.152)$, $\mathrm{Zn}(0.122), \mathrm{Pb}(0.328)$ and $\mathrm{Cd}(0.334)$, but all of them are lower than 1 for all trace metals $(B C F<1)$, indicating that accumulation was not found in the sea cucumber $H$. floridana. Results highlighted the fact that regardless these organisms acquired their food from sediments, these organisms have excretion mechanisms that prevent a bioaccumulation greater than their metabolic and physiological needs require, at least in the conditions in which this study was carried out. The above indicates a high accumulation of $\mathrm{Hg}$, possibly due to the high bioavailability of $\mathrm{Hg}$ in sediments near the study area as reported by Paternina-Uribe [21]. For this reason, $H$. floridana could be considered as a biomonitor to determine the influence of $\mathrm{Hg}$ contamination on the ecosystem.

As was pointed out above, metals such as $\mathrm{Cu}$ and $\mathrm{Zn}$ have important physiological functions unlike to $\mathrm{Hg}, \mathrm{Cd}$ and $\mathrm{Pb}$. These nutrients are absorbed and eliminated frequently, and maintaining the levels through homeostatic mechanisms, as excess can be toxic and scarcity can generate physiological deficiencies. Hence, despite presenting the highest concentrations in tissue and sediments, BCF values for $\mathrm{Cu}$ and $\mathrm{Zn}$ are very low. Sea cucumbers are classified commercially important according to the different type of species, organoleptic characteristics (color, appearance, smell, body thickness), abundance and demand in the global market [15]. Although sea cucumbers are consumed as part of the Asian tradition, for their medicinal benefits and as part of culinary delicacy [6, 9], the $H$. floridana species still does not have great value as food, although the constant pressure and overexploitation of other sea cucumbers could increase their future demand.

\subsection{Ecological risk potential assessment}


To evaluate the ecological risk of metals in sediments, different indices were used such as the estimated potential ecological risk factor $\left(\mathrm{Er}_{\mathrm{i}}\right)$ with individual elements in conjunction with the full potential ecological risk index (PRI), sediment quality guidelines (SQGs), as well as the mean effect coefficient values (M-ERM-Q) (Table 1). As it can be seen, the content of $\mathrm{Pb}, \mathrm{Zn}$ and $\mathrm{Cd}$ were lower than the corresponding values of effects range low (ERL), effects range median (ERM), probable effect level (PEL), lowest effect level (LEL) and severe effect level (SEL). Levels of $\mathrm{Cu}$ were greater than ERL, TEL, and LEL, whereas $\mathrm{Hg}$ shows higher values than TEL in all the stations, except S1 and S2. This indicated that $\mathrm{Cu}$ and $\mathrm{Hg}$ levels in sediments can cause adverse biological effects on biota $[43,44]$. Moreover, $\mathrm{Cu}$ had the highest concentration in tissue and $\mathrm{Hg}$ was the metal with the highest BCF, validating the biological effects that may occur in $H$. floridana. Moreover, stations S3, S4 and S7 presented a $21 \%$ probability of sediment toxicity $(0.11=$ M-ERM$\mathrm{Q}<0.5)$. As a function of $\mathrm{Er}_{\mathrm{i}}$, sediments were classified with a potential ecological risk factor from low $\left(E r_{i}<40\right)$ to considerable $\left(E_{i}=80-160\right)$. Afterward, $\mathrm{Hg}$ and $\mathrm{Cd}$ exhibited considerable ecological risk, unlike $\mathrm{Cu}, \mathrm{Zn}$ and $\mathrm{Pb}$ displayed low ecological risk $\left(E r_{i}<40\right)$. Likewise, surface sediments presented moderate ecological risk indices (RI, 150-300) in more than half of the samples (57\%), with higher values in S3. Finally, according to the PLI values, the surface sediments in all the sampling sites indicated an environmental deterioration $(P L \mid>1)$, with greater impact for the different stations depending on the concentrations of metals in the following decreasing order: $\mathrm{Cu}>\mathrm{Zn}>\mathrm{Hg}>\mathrm{Pb}>\mathrm{Cd}$.

\subsection{Human health risk assessment}

Table 2 shows maximum allowable daily sea cucumber consumption rate $\left(\mathrm{CR}_{\text {lim }}\right)$. As can be seen, the amount of daily consumption allowed ranged from 0.07 to $3.81 \mathrm{~kg} / \mathrm{day}$ regardless of the metal considered. According to the calculated $\mathrm{CR}_{\text {lim }}$ values and considering that $H$. floridana in Colombia has a weight between 0.07 and $0.2 \mathrm{~kg}$, its 
consumption is not recommended for children, due to the levels of $\mathrm{Cu}, \mathrm{Hg}$ and $\mathrm{Pb}$ reported. There is no expected risk to adults, although an increase of the maximum daily intake can lead to an increased risk. Indeed, excess of sea cucumber consumption (e.g. more than 3 to 5 per day, every single day, and depending on their size) can pose a threat to human health, due to $\mathrm{Cu}$ and $\mathrm{Hg}$ exposure.

\subsection{Multivariate statistical analysis}

In order to evaluate the relationship between trace metals and groups, some of the multivariate analysis techniques were carried out, including Pearson correlation and PCA with Varimax rotation to maximize the sum of the variance of the factor coefficients. Table 3 shows the values of the Pearson correlation coefficients in tissues $(t)$ and sediments (sed). In sediments, $\mathrm{Pb}$ (sed) present a statistically significant correlation with $\mathrm{Cu}(\mathrm{sed})$ and Cd(sed) $(r=0.790$ and $r=0.767, p<0.05$, respectively), indicating that these metals could have similar origin. Likewise, $\mathrm{Zn}(\mathrm{sed})$ presented a strong positive correlation with $\mathrm{Zn}(\mathrm{t})$ and $\mathrm{Hg}(\mathrm{t})$ in tissues $(r=0.958 ; \mathrm{p}<0.01$ and $r=0.776, \mathrm{p}<0.05$, respectively) indicating the metals absorption influence of $\mathrm{Zn}$ and $\mathrm{Hg}$ by $\mathrm{H}$. floridana. Finally, $\mathrm{Cd}(\mathrm{t})$ in tissue also showed a strong statistical correlation with $\mathrm{Hg}(\mathrm{sed})$ in sediments $(r=0.829, \mathrm{p}<0.05)$.

The PCA method led to a reduction of the initial size of the data set to two components that explained $73.1 \%$ of the data variation (Figure 3). Therefore, these two factors played an important role in explaining metal contamination in the study area. According to the matrix of rotated components, trace metals $\mathrm{Cu}, \mathrm{Hg}, \mathrm{Pb}$ and $\mathrm{Cd}$ in sediments had higher loads in the first component (PC1), while trace metals in tissues $\mathrm{Cu}, \mathrm{Zn}$ and $\mathrm{Hg}$ had a higher load in the second component (PC2). Hence, $\mathrm{Pb}$ (sed) showed a high contribution in PC1 (0.984) together with $\mathrm{Cu}(\mathrm{sed})(0.828)$ and $\mathrm{Cd}(\mathrm{sed})(0.705)$, suggesting that these metals may have same anthropogenic sources, which is also supported by the high correlations obtained between $\mathrm{Pb}$ and $\mathrm{Cu}$, and $\mathrm{Pb}$ and $\mathrm{Cd}$ (Table 3). These three trace 
metals are well-known markers of agricultural activities, specifically related to the application of phosphate-based fertilizers $[45,46]$. The application of Cu-based pesticides and fungicides on long-term soils contributes to the increased accumulation of this metal potentially accumulated in sediments [47]. Results for $\mathrm{Pb}$ can also be attributed to petrogenic sources due to the transport of crude oil in a nearby oil port and tourist activities with gasoline engines. However, Burgos-Nuñez et al. [20] reported that there is no relationship between the concentration of metals and hydrocarbon contamination in sediments near the study area. Hg sed also has a contribution in PC1 (0.721), however, the anthropogenic source of $\mathrm{Hg}$ sed should be different because there are no significant correlations with other metals except with $\mathrm{Cd} \mathrm{t}(\mathrm{p}<0.05)$ (Table 3$)$. The use of fungicides containing phenylmercury was very common in this area, as well as the massive aerial fumigation of rice fields with mercurial agrochemicals in previous years, which were banned by the ICA (Colombian Institute of Agriculture) according to the resolution 2189 of 1974, more than 50 years ago. Previous studies have demonstrated the presence of metals in sediments [22], in soils of the middle and lower basin of the Sinú River [23], and in fish species in the upper basin of the Sinú River [18], where soil flooding possibly accelerated the washing process and the metal extraction [22]. Therefore, the Sinú River could be considered a potential source of metals through water network interconnected with the study area that can increase the content of metals in sediments $[17,20,21]$. Contribution of $\mathrm{Zn}$ sed (0.911), Zn t (0.912) and $\mathrm{Hg} \mathrm{t}$ (0.841) are shown in PC2 in Figure 3, additional to a strong Pearson's correlation between the metals (Table 3). These significant correlations indicate that they may be derived from similar sources, originated from anthropogenic activities, and possibly the presence of $\mathrm{Zn}$ in sediments and tissues, influences the absorption of $\mathrm{Hg}$ by $\mathrm{H}$. floridana. Intensive livestock activities [21] near the study area can contribute between $37-40 \%$ of $\mathrm{Zn}$ to the soil through manure, which can eventually be deposited in sediments [48]. Hence, $\mathrm{Zn}$ is probably associated to traditional 
agricultural practices developed in the area, such as fertilization, irrigation and the application of pesticides that are considered probable anthropogenic sources of trace metal accumulation $[49,50]$.

\section{Conclusions}

Results suggested that $H$. floridana could be used as a bioindicator species in studies of monitoring metal contamination in the Caribbean Sea, with special attention to the highly statistically significant correlation between $\mathrm{Zn}$ in tissue and $\mathrm{Zn}$ in sediments. Metal pollution in sediments came mainly from anthropogenic sources through intense agricultural activities by the application of agrochemicals and fertilizers. Moreover, metal levels in sediments and biota showed a similar decreasing trend as follows: $\mathrm{Cu}>\mathrm{Zn}>\mathrm{Hg}>\mathrm{Pb}>\mathrm{Cd}$.

The contamination degree calculated in function of the pollution load index and the potential ecological risk assessment revealed a potential moderate ecological risk towards $H$. floridana together with a great environmental deterioration in surface sediments for the different sampling stations.

Results for health risk assessment based on the maximum allowable daily consumption rate $\left(\mathrm{CR}_{\text {lim }}\right)$ suggest that children should limit or avoid its consumption. It seems there is no risk to adults, however an increase of the maximum daily intake can lead to an increased risk.

This is the first study of accumulation of metals in $\mathrm{H}$. floridana in tropical estuaries, and the results provided in this study is expected to serve as a useful guide for future management of the bay concerning potentially pollution activities that impact in marine aquatic ecosystems of the Colombian Caribbean coast. 


\section{Acknowledgments}

The authors want to thank the University of Córdoba, Montería-Colombia, the Applied and Environmental Water Chemistry Group, and the Laboratory of Toxicology and Environmental Management.

\section{References}

1. Whitall D, Pait A, lan Hartwell S (2015) Chemical contaminants in surficial sediment in Coral and Fish Bays, St. John, U.S. Virgin Islands. Mar Environ Res 112:1-8

2. Tuzen M (2009) Toxic and essential trace elemental contents in fish species from the Black Sea, Turkey. Food Chem Toxicol 47:1785-1790

3. Spanopoulos-Zarco P, Ruelas-Inzunza J, Meza-Montenegro M, et al (2014) Health risk assessment from mercury levels in Bycatch fish species from the Coasts of Guerrero, Mexico (Eastern Pacific). Bull Env Contam Toxicol 93:334-338

4. Zhang C, Yu ZG, Zeng GM, et al (2014) Effects of sediment geochemical properties on heavy metal bioavailability. Env Int 73:270-281

5. Uthicke S (2001) Nutrient regeneration by abundant coral reef holothurians. J Exp Mar Bio Ecol 265:153-170

6. Van den Hoek LS, Bayoumi EK (2017) Review global management utilization of sea cucumbers. IOSR J Pharm Biol Sci 12:1-7

7. Toral-Granda V, Lovatelli A, Vasconcellos M (2008) Sea cucumbers: A global review of fisheries and trade. FAO Fish Aquac Tech Pap 516:213-229

8. Purcell SW, Ngaluafe P, Foale SJ, et al (2016) Multiple factors affect socioeconomics and wellbeing of artisanal sea cucumber fishers. PLoS One 
11:e0165633

9. Purcell SW, Ngaluafe P, Lalavanua W, Ceccarelli DM (2018) Market price trends of Latin American and Caribbean sea cucumbers inform fisheries management. Reg Stud Mar Sci 17:127-132

10. Mohammadizadeh M, Bastami KD, Ehsanpour M, et al (2016) Heavy metal accumulation in tissues of two sea cucumbers, Holothuria leucospilota and Holothuria scabra in the northern part of Qeshm Island, Persian Gulf. Mar Pollut Bull 103:354-359

11. Ahmed Q, Mohammed A, Bat L (2017) Assessment of heavy metals concentration in Holothurians, sediments and water samples from coastal areas of Pakistan (northern Arabian Sea). J Coast Life Med 5:191-201

12. Purcell SW (2014) Value, Market Preferences and Trade of Beche-De-Mer from Pacific Island Sea Cucumbers. PLoS One 9:e95075

13. Bordbar S, Anwar F, Saari N (2011) High-value components and bioactives from sea cucumbers for functional foods-A review. Mar Drugs 9:1761-1805

14. Fabinyi M (2012) Historical, cultural and social perspectives on luxury seafood consumption in China. Env Conserv 39:83-92

15. Purcell SW, Samyn Y, Conand C (2012) Commercially important sea cucumbers of the world. FAO Species Catalogue for Fishery Purposes. Rome

16. Sánchez H, Ulloa G, Tavera H, Gil H (2005) Corporación de los Valles del Sinú y San Jorge CVS. Plan De Manejo Integral - Corporación Nacional de Investigación y Fomento Forestal - CONIF. Zona de Uso Sostenible del Sector Estuarino de la Bahía de Cispatá. Departamento de Córdoba - Colombia

17. Ruiz M, Bernal G, Polania J (2008) Influencia del Río Sinú y el mar Caribe en el 
sistema lagunar de Cispatá. Bol Invest Mar Cost 37:29-49

18. Ruiz-Guzman J, Marrugo-Negrete JL, Diez S (2014) Human exposure to mercury through fish consumption: risk assessment of riverside inhabitants of the Urrá reservoir. Colomb Hum Ecol Risk Assess 20:1151-1163

19. INVEMAR (2003) Instituto de Investigaciones Marinas y Costeras José Benito Vives de Andréis. Diagnóstico de la Calidad Ambiental Marina en el Caribe y Pacífico Colombiano. Red de Vigilancia de la Calidad de las Aguas marinas y Costeras.

20. Burgos-Núñez S, Navarro-Frómeta A, Marrugo-Negrete J, et al (2017) Polycyclic aromatic hydrocarbons and heavy metals in the Cispata Bay, Colombia: A marine tropical ecosystem. Mar Pollut Bull 120:379-386

21. Paternina-Uribe R (2011) Evaluación de la contaminación por metales pesados en la Ciénaga la Soledad y Bahía de Cispatá, cuenca del Bajo Sinú, departamento de Córdoba Departamento de Biología. Tesis de Maestría Universidad de Córdoba, Montería

22. Feria J, Marrugo J, Gonzalez H (2010) Heavy metals in Sinú River, department of Córdoba, Colombia, South America. Rev Fac Ing Univ Antioq 55:35-44

23. Marrugo-Negrete J, Pinedo-Hernández J, Díez S (2017) Assessment of heavy metal pollution, spatial distribution and origin in agricultural soils along the Sinú River Basin, Colombia. Environ Res 154:380-388

24. Medina R, Zetina C, Comas M, Pat R (2004) Concentración de Cd, Cr, Cu y Pb en sedimentos y en tres especies de pepino de mar (Holothuroidea) de las costas del Estado de Yucatán, México. Ing Rev Académica 8:7-19

25. USEPA (1998) Mercury in Solids and Solutions by Thermal Decomposition. Amalgamation and Atomic Absorption Spectrophotometry (Method 7473) 
26. USEPA (2007) SW-846 Test Method 3051A: Microwave Assisted Acid Digestion of Sediments, Sludges, Soils, and Oils. 30

27. Karadede-Akin H, Ünlü E (2007) Heavy metal concentrations in water, sediment, fish and some benthic organisms from Tigris river, Turkey. Environ Monit Assess $131: 323-337$

28. Abdallah M, Abdallah A (2008) Biomonitoring study of heavy metals in biota and sediments in the South Eastern coast of Mediterranean Sea, Egypt. Env Monit Assess 146:139-145

29. Aydin-Onen S, Kucuksezgin F, Kocak F, Acik S (2015) Assessment of heavy metal contamination in Hediste diversicolor (O.F. Müller, 1776) Mugil cephalus (Linnaeus, 1758) and surface sediments of Bafa Lake (eastern Aegean). Environ Sci Pollut Res 22:8702-8718

30. Islam MA, Al-mamun A, Hossain F, et al (2017) Contamination and ecological risk assessment of trace elements in sediments of the rivers of Sundarban mangrove forest, Bangladesh. Mar Pollut Bull 124:356-366

31. USEPA (2000) Guidance for assessing chemical contaminant data for use in fish advisories. Volume 2: Risk assessment and fish consumption limits. Third Edition. 823-B-00-008

32. USEPA (2015) Integrated Risk Information System-Database (IRIS), Philadelphia PA; Washington, DC. https://cfpub.epa.gov/ncea/iris_drafts/atoz.cfm. Accessed 18 Jun 2020

33. WHO (2018) Evaluations of the Joint FAO/WHO Expert Committee on Food Additives (JECFA). https://apps.who.int/food-additives-contaminants-jecfadatabase/search.aspx. Accessed 18 Jun 2020 
34. USEPA (2014) Human Health Evaluation Manual, Supplemental Guidance: Update of Standard Default Exposure Factors OSWER Directive 9200. https://www.epa.gov/risk/oswer-directive-92001-120. Accessed 18 Jun 2020

35. EFSA (2010) European Food Safety Authority. Scientific Opinion on Lead in Food. EFSA J. 8. http://dx.doi.org/10.2903/j.efsa.2010.1570. Accessed 18 Jun 2020

36. Wang YG, Zhang CY, Rong XJ, et al (2004) Diseases of cultured sea cucumber (Apostichopus japonicus) in China. In: Advances in sea cucumber aquaculture and management. FAO Fisheries Technical Paper 463. p 297

37. Aydın M (2008) The commercial sea cucumbers fishery in Turkey SPC Beche de Mer. Inf Bull 28:40-43

38. Turk Culha S, Dereli H, Karaduman FR, Culha M (2016) Assessment of trace metal contamination in the sea cucumber (Holothuria tubulosa) and sediments from the Dardanelles Strait (Turkey). Environ Sci Pollut Res 23:23:11584-11597

39. Tunca E, Aydın M, Şahin Ü (2016) Interactions and accumulation differences of metal(loid)s in three sea cucumber species collected from the Northern Mediterranean Sea. Environ Sci Pollut Res 23:21020-21031

40. McAloon KM, Mason RP (2003) Investigations into the bioavailability and bioaccumulation of mercury and other trace metals to the sea cucumber, Sclerodactyla briareus, using in vitro solubilization. Mar Pollut Bull 46:1600-1608

41. Warnau M, Dutrieux S, Ledent G, et al (2006) Heavy Metals in the Sea Cucumber Holothuria tubulosa (Echinodermata) from the Mediterranean Posidonia oceánica Ecosystem: body Compartment, Seasonal, Geographical and Bathymetric Variations. Env Bioindic 1:268-285

42. Morgano MA, Rabonato LC, Milani RF, et al (2011) Assessment of trace elements 
in fishes of Japanese foods marketed in Sao Paulo (Brazil). Food Control 22:778785

43. Long ER, Morgan LG (1991) The potential for biological effects of sediment-sorbed contaminants tested in the national status and trends program. In: NOAA Technical Memorandum NOS OMA 52. 2. US National Oceanic and Atmospheric Administration, Seattle, Washington.

44. Long ER, MacDonald DD, Severn CG, Hong BC (2000) Classifying probabilities of acute toxicity in marine sediments with empirically derived sediment quality guidelines. Environ Toxicol 19:2598-2601

45. Nziguheba G, Smolders E (2008) Inputs of trace elements in agricultural soils via phosphate fertilizers in European countries. Sci Total Environ 390:53-57

46. Atafar Z, Mesdaghinia A, Nouri J, et al (2010) Effect of fertilizer application on soil heavy metal contamination. Environ Monit Assess 160:83-89

47. Epstein L, Bassein S (2001) Pesticide application of copper on perennial crops in California, 1993 to 1998. J Environ Qual 22:335-348

48. Nicholson FA, Smith SR, Alloway BJ, et al (2003) An inventory of heavy metals inputs to agricultural soils in England and Wales. Sci Total Environ 311:205-219

49. Haynes D, Johnson JE (2000) Organochlorine, heavy metal and polyaromatic hydrocarbon pollutant concentrations in the Great Barrier Reef (Australia) environment: a review. Mar Pollut Bull 41:267-278

50. Nacke H, Goncalves AC, Schwantes D, et al (2013) Availability of heavy metals $(\mathrm{Cd}, \mathrm{Pb}$, and $\mathrm{Cr})$ in agriculture from commercial fertilizers. Arch Environ Contam Toxicol 64:537-544 
Table 1. Sediment Quality Guidelines (SQG; $\mu \mathrm{g} / \mathrm{g} \mathrm{dw}$ ), PLI and RI classification

\begin{tabular}{|c|c|c|c|c|c|c|c|c|c|c|c|c|c|c|c|}
\hline & \multicolumn{9}{|c|}{ Stations } & \multicolumn{4}{|c|}{ NOAA } & \multicolumn{2}{|c|}{ CMEE } \\
\hline & 1 & 2 & 3 & 4 & 5 & 6 & 7 & Mean & $\overline{E r_{i} \text { (media) }}$ & ERL & ERM & TEL & PEL & LEL & SEL \\
\hline $\mathrm{Hg}$ & 0.102 & 0.121 & 0.143 & 0.148 & 0.132 & 0.136 & 0.142 & 0.132 & 125.7 & 0.15 & 0.71 & 0.13 & 0.70 & 0.2 & 2.0 \\
\hline $\mathrm{Cu}$ & 57.36 & 53.85 & 55.76 & 61.42 & 58.23 & 54.78 & 62.87 & 55.70 & 29.6 & 34 & 270 & 18.7 & 108.2 & 16 & 110 \\
\hline $\mathrm{Zn}$ & 46.53 & 55.61 & 58.21 & 48.98 & 52.71 & 50.98 & 56.35 & 52.80 & 0.4 & 150 & 410 & 124 & 271 & 120 & 820 \\
\hline Cd & 0.054 & 0.065 & 0.058 & 0.078 & 0.067 & 0.053 & 0.059 & 0.062 & 124.0 & 1.2 & 9.6 & 0.68 & 4.21 & 0.6 & 10 \\
\hline $\mathbf{P b}$ & 0.088 & 0.091 & 0.094 & 0.122 & 0.097 & 0.092 & 0.107 & 0.099 & 15.4 & 46.7 & 218 & 30.24 & 112.18 & 31 & 250 \\
\hline RI & 248.4 & 287.8 & 295.8 & 347.9 & 305.1 & 278.4 & 302.5 & 295.1 & & & & & & & \\
\hline M-ERM-Q & 0.095 & 0.102 & 0.111 & 0.113 & 0.108 & 0.105 & 0.115 & 0.107 & & & & & & & \\
\hline PLI & 3.1 & 3.5 & 3.6 & 4.0 & 3.6 & 3.4 & 3.7 & 3.5 & & & & & & & \\
\hline
\end{tabular}

NOAA: National Oceanic and Atmospheric Administration, USA; CMEE: Canadian sediment quality guidelines for the protection of aquatic life 
Table 2. Maximum allowable daily consumption rate ( $\left.\mathrm{CR}_{\text {lim }}\right)$ of $H$. floridana expressed in $\mathrm{kg}$ per day by different age groups.

\begin{tabular}{|c|c|c|c|c|}
\hline \multirow{2}{*}{ Metal } & \multirow{2}{*}{ Concentration (mg/kg) } & \multirow{2}{*}{ RfD (mg/kg bw/day)a } & \multicolumn{2}{|c|}{ CR/lim (kg/day) } \\
\hline & & & Childrenb & Adultsc \\
\hline $\mathrm{Cu}$ & 8.75 & 0.04 & 0.07 & 0.37 \\
\hline $\mathrm{Zn}$ & 6.44 & 0.3 & 0.70 & 3.73 \\
\hline $\mathrm{Hg}$ & 0.081 & $5.7 \times 10_{-4}$ & 0.11 & 0.56 \\
\hline $\mathbf{P b}$ & 0.032 & d $6.3 \times 10_{-4} /$ e $1.5 \times 10-3 /$ f $5 \times 10-4$ & 0.23 & d $1.58-$ e 3.75 \\
\hline Cd & 0.021 & 0.001 & 0.71 & 3.81 \\
\hline
\end{tabular}

a Values of oral reference dose (RfD) from [32, 33]

$\mathrm{b} B W=15 \mathrm{~kg}$ and $\mathrm{c} B W=80 \mathrm{~kg}[34]$

Values for $\mathrm{Pb}$ : d BMDL 10 for nephrotoxicity (adults), e BMDL01 for cardiovascular effects (adults), and fBMDL01 for developmental neurotoxicity (children) [35] 
Table 3. Correlation of Pearson among metals in sediments and tissues

\begin{tabular}{|c|c|c|c|c|c|c|c|c|c|c|}
\hline & $\mathrm{Cu} \mathrm{ta}_{\mathrm{a}}$ & Cu sedb & $\mathrm{Znt}$ & Zn sed & $\mathrm{Hg} \mathrm{t}$ & $\mathrm{Hg}$ sed & $\mathrm{Pb} \mathrm{t}$ & $\mathrm{Pb}$ sed & $\mathrm{Cd} \mathrm{t}$ & $\mathrm{Cd} \mathrm{sec}$ \\
\hline Cut & 1 & & & & & & & & & \\
\hline Cu sed & -0.058 & 1 & & & & & & & & \\
\hline $\mathrm{Znt}$ & 0.566 & 0.070 & 1 & & & & & & & \\
\hline Zn sed & 0.455 & -0.114 & $0.958^{* *}$ & 1 & & & & & & \\
\hline $\mathrm{Hg} \mathrm{t}$ & 0.504 & 0.140 & 0.724 & $0.776^{*}$ & 1 & & & & & \\
\hline $\mathrm{Hg}$ sed & -0.073 & 0.407 & 0.453 & 0.457 & 0.363 & 1 & & & & \\
\hline $\mathrm{Pb} \mathrm{t}$ & 0.687 & -0.598 & 0.238 & 0.276 & 0.136 & -0.095 & 1 & & & \\
\hline $\mathrm{Pb}$ sed & -0.244 & $0.790^{*}$ & 0.001 & -0.090 & 0.141 & 0.688 & -0.572 & 1 & & \\
\hline $\mathrm{Cdt}$ & 0.208 & 0.628 & 0.377 & 0.330 & 0.536 & $0.829^{*}$ & -0.006 & 0.693 & 1 & \\
\hline Cd sed & -0.132 & 0.406 & 0.018 & -0.085 & -0.046 & 0.423 & -0.430 & $0.767^{*}$ & 0.233 & 1 \\
\hline
\end{tabular}




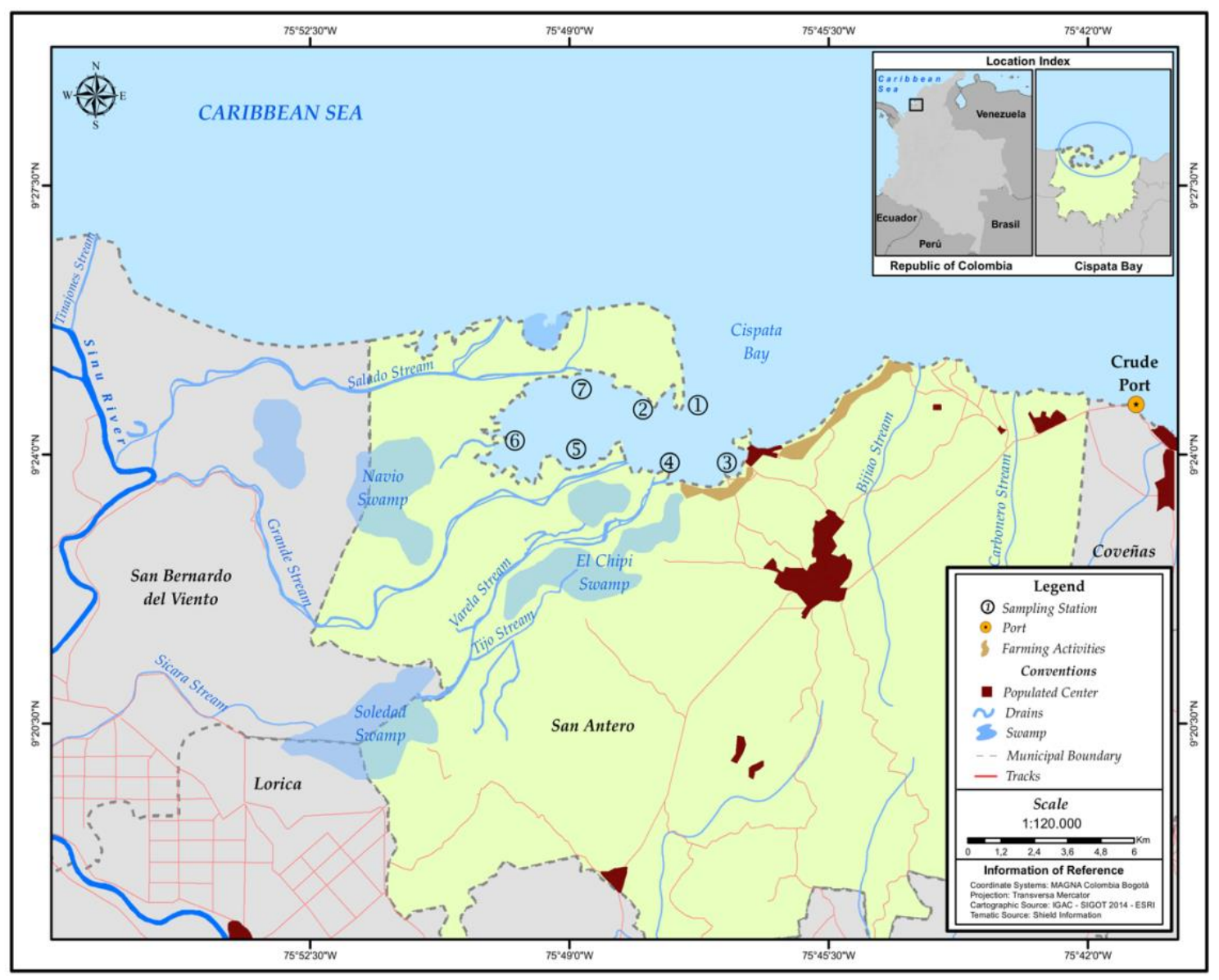

Figure 1. Study area and sampling stations from the Cispatá Bay, Colombia. 
a)

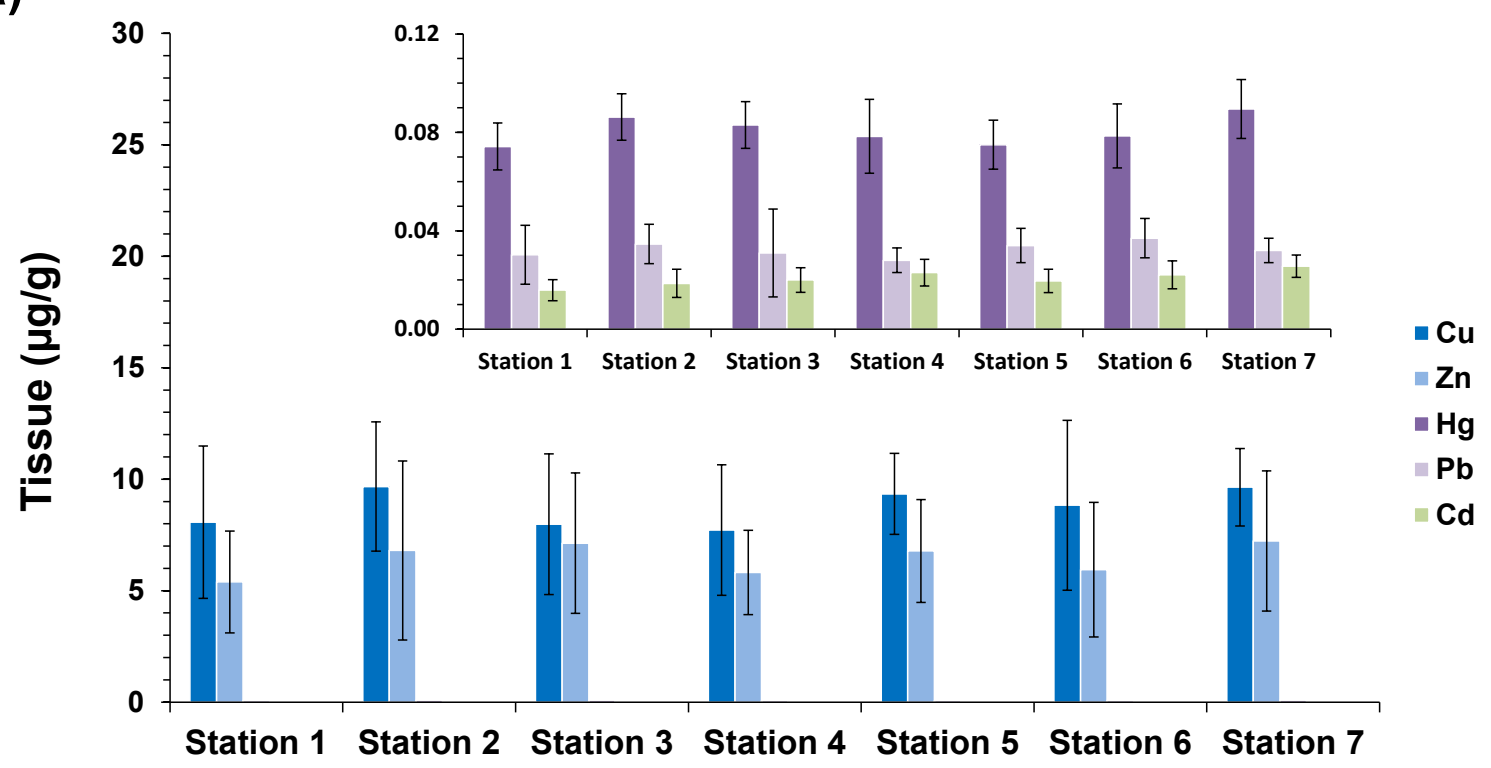

b)

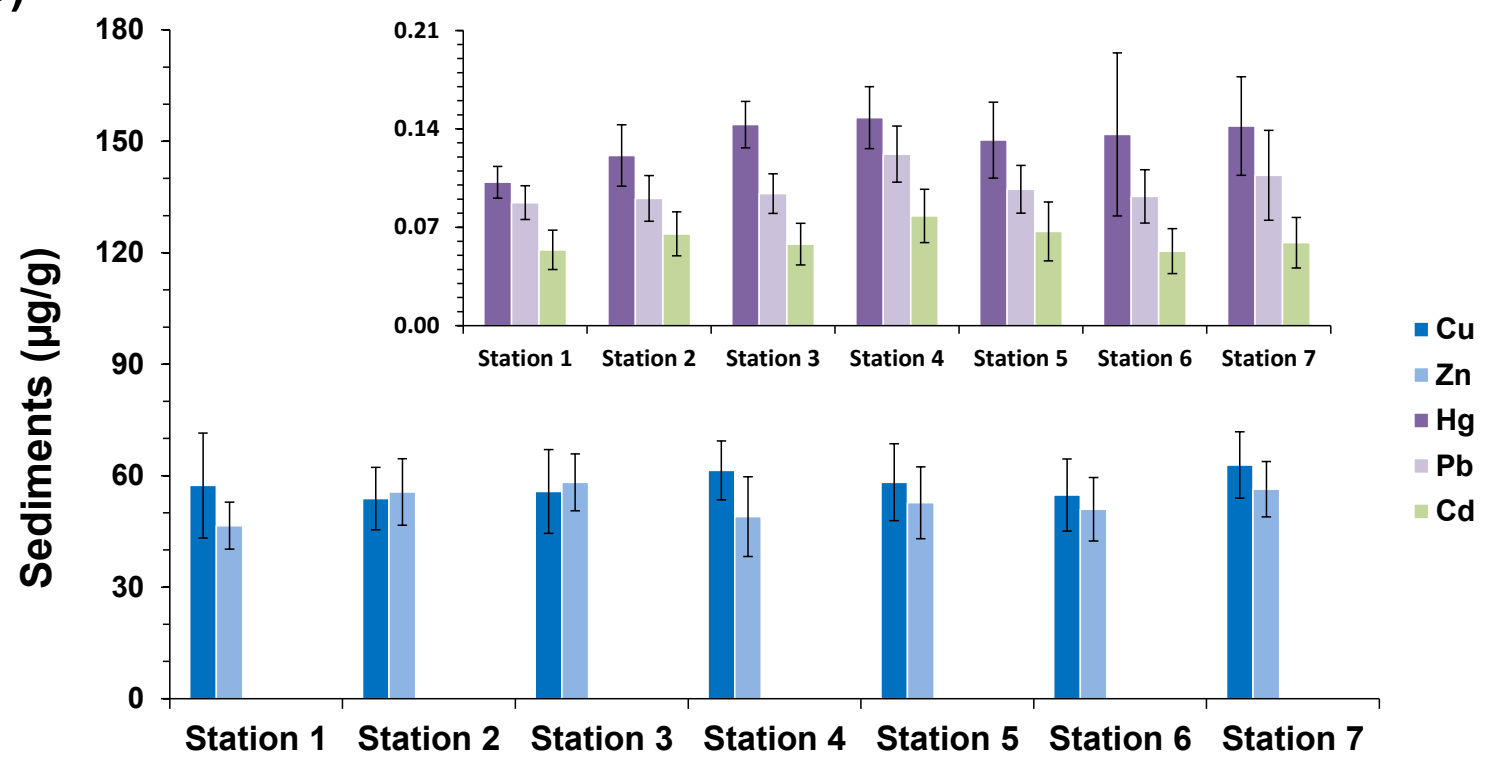

Figure 2. Trace metal concentrations in (a) tissues, and (b) sediments 


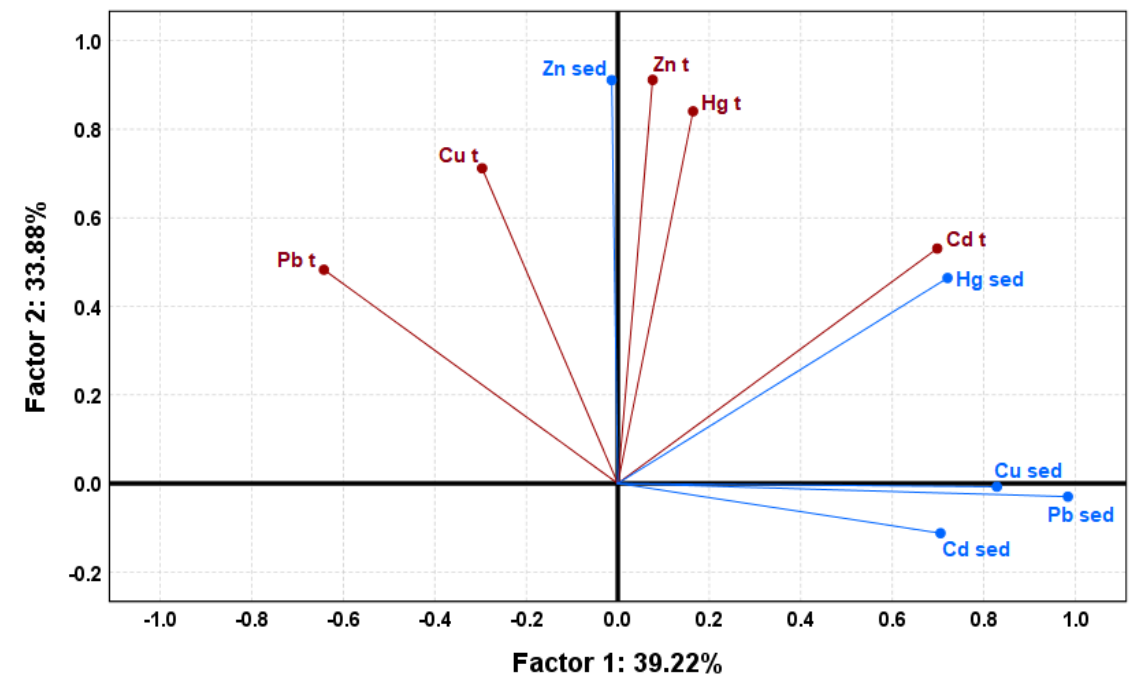

Figure 3. Principal Component Analysis (PCA) 


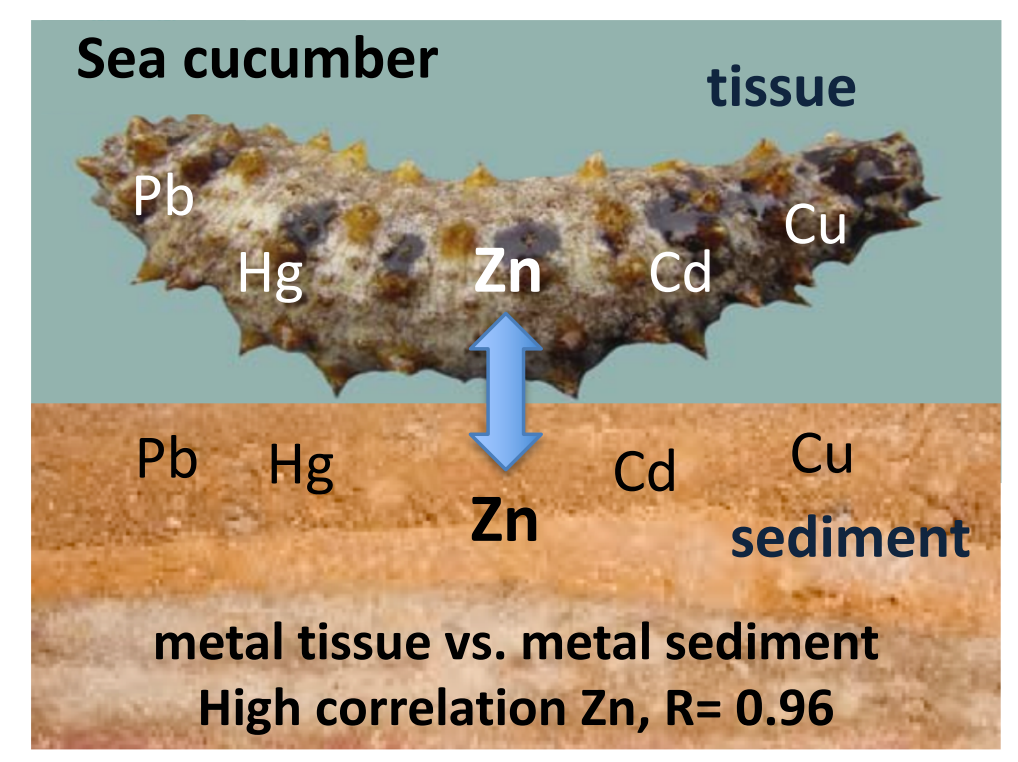

graphical Abstract

$$
\text { High correlation } \mathrm{Zn}, \mathrm{R}=\mathbf{0 . 9 6}
$$

